\title{
TECHNOLOGY EXPOSURE IN LARGE PORTUGUESE CATHOLIC FAMILIES
}

\author{
Adriana José de Oliveira and Luciana Oliveira \\ CEOS.PP ISCAP Polytechnic of Porto \\ Rua Jaime Lopes Amorim, s/n 4465-004 S. Mamede de Infesta, Matosinhos, Portugal
}

\begin{abstract}
Despite the tremendous opportunities provided by current unparalleled advancements in communication and connectivity among individuals, many concerns have been raising, from many fields, regarding the effects of intensive use and exposure to technology in the escalation of social dehumanization. As the main social control mechanism, religion diffuses normative instruments that are not immediately open to progress, as they typically propel a broader resistance to normative, behavioral and social change. In this paper, we focus on the relation between religious practice and the use of technology, and on how religious families curate for the family well-being while conceding to technology exposure within their homes. Large catholic families were selected as the subject of research as they constitute, at least in Portugal, as the most conservative and resistant to change group. A mixed-methods research strategy, with surveys and interviews, was used to identify how these families regulate the use of technology, how and when they use digital devices and internet connection, and which are the norms and strategies used to preserve the values of the Catholic church while engaging with digital devices and networks.
\end{abstract}

\section{KEYWORDS}

Technology Exposure, WWW, Large Catholic Families

\section{INTRODUCTION}

Technology and the WWW have brought multiple changes into the work and family fields (Livingstone, 2002, Roe, 2000, Toffler, 1984 ). The impacts and changes brought by the $4^{\text {th }}$ Industrial Revolution (4IR) have been and will remain on the agenda of much of the controversial scientific, technological, economic and social debate. Unlike previous industrial revolutions, which were characterized by advancements in technology, the 4IR biggest impact is to improve quality of life and reduce inequalities among the worlds' population. This marks a new era of metaphorical and literal technology embedding into individuals' bodies and environment. As much of the potential of this era relies on advances on communication and connectivity, a social revolution regarding the way we live, work and relate to one another is unavoidable.

Despite the tremendous opportunities provided by current unparalleled advancements in communication and connectivity among individuals, many concerns have been raising, from many fields, regarding the effects of intensive use and exposure to technology in the escalation of social dehumanization.

This scenario, which affects societies at large, collides directly with the core of the formation of individuals, where fundamental principles and values are learned, by hindering the necessary socialization in the family nucleus. Technology has become the key vehicle to connect family members when they are apart as much as it has become the main barrier to keep them from socializing when they are together.

A notorious stream of warnings and precautions associated with the need of maintenance of off-screen socialization and off-line communication and leisure has been advocated by psychologists, neurologists, pediatricians, and other health and social authorities. Curiously, most of these recommendations tend to recall, recapture and boost what could be understood as the core pre-modern and pre-technological most traditional social and family values, framed into sets of precautionary cross-filed measures aimed at preserving the family well-being. As the main social control mechanism, religion diffuses normative instruments that are not most open to any type of immediate progress, as they typically propel a broader resistance to normative, behavioral and social change. 
In this context, families with high prominent religious involvement appear most prone to resist to the technological advancements which are believed to result in the corruption of the families' core values, dehumanization, isolation, neglection and social marginalization of individuals in close circles and in society. This happens because when highly involved in religious practices, there is a regular direct contact with a set of reinforced normative that establish morals and conduct on how to manage, among others, the integration of technology in the family environment without corrupting it. Since religion has always been the most powerful mean for the preservation of self-regulation and self-control, we believe that, within it, it is possible to identify and report on behaviors, strategies, norms and values they may be useful in addressing some of the current concerns of the dehumanization of families and individuals.

However, very little research has been devoted to the relation between religious practice and the use of technology, and on how religious families curate for the family well-being while conceding to technology exposure within their homes. In this work, large catholic families were selected as the subject of research as they constitute, at least in Portugal, as the most conservative and resistant to change group. A mixed-methods research strategy, with surveys and interviews, was used to identify how these families regulate the use of technology, how and when they use digital devices and internet connection, and which are the norms and strategies used to preserve the values of the Catholic church while engaging with digital devices and networks.

\section{EXPOSURE TO TECHNOLOGY: TIME AND PLACE}

Acknowledging the levels of exposure, role and power of technology, and namely internet access, the need to claim locations for certain purposes has grown (Morgan, 1996). In fact, internet access began by occupying public spaces and later the private ones, resulting not only in different ways to look at the private and public life, but also turning the family environment into a more collectivist or individualistic interaction space (Livingstone, 2002).

In Portugal, in 2017 (INE, 2017), 77\% of households had internet access, with a large majority of families who have children. Portugal is one of the countries where children and teenagers are more exposed to technology and internet in their bedrooms (67\%), being above the European average (49\%). Among these, the ones with higher economic resources use their bedrooms and shared spaces (86\%), as opposed to those who have lower income and less access to the Internet in shared spaces (73\%) (Ponte et al., 2012).

Private and individualized use of the internet has been growing concerning the internet's possession, contact with outer world, creation of original content in platforms such as Youtube, Facebook or blogs without parental supervision, which has been leading to negotiations or conflicting situations in the family environment (Livingstone, 2002, Morgan, 1996, Monteiro and Policarpo, 2011). Understanding teenager's use of the ICTs continues to be the key to comprehend the internet's omnipresence in people's homes, the conditions of access and involvement, the lifestyles of both teenagers and parents, the differences between amount, quality and consumption and the attitudes and values of the families. Given all this, religion, age group, ethnicity, gender and regional and national cultures' differences and similarities must be considered, regardless of variables such as "privatization, individualization and consumerism" (Livingstone, 2002, Roberts, 2000).

Individuals need to claim their own time, like time to take a shower, eat (Morgan, 1996), or surf the web. Teenager's behavior towards the internet usage leads to time being more dedicated to these platforms rather than the family. This increases individualism and isolation in the family environment (Livingstone, 2002). Mesch's model (2006), represented in Figure 1, establishes direct and indirect connections between several key variables linked to the use of the internet and the family settings. 


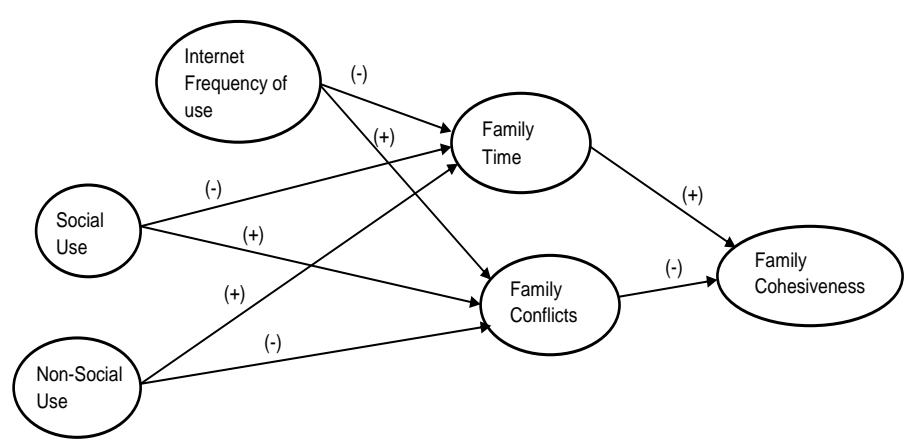

Figure 1. Behavior of uses model (Mesch, 2006)

According to the author, the time dedicated to the internet usage represents time that is taken away from the family. This may lead to low levels of family cohesion and bonding and several family conflicts (Lee, 2009, Nie et al., 2004, Lenhart et al., 2001). Contrarily, when one dedicates more time to the family than to the media, one may see higher levels of family cohesion and fewer family conflicts. This equation may become more relevant if applied to bigger families, since there is more competition among members for the time dedicated to the media (and more competition for personal attention). This may lead to conflicts between parents and their children, because teenagers may find sharing digital resources consists of restrictions on freedom (Mesch, 2006).

In 2018, 79\% of Portuguese individuals had internet in their homes (INE, 2018) and according to the study 'Eu kids Online', 87\% of teenagers had access to the internet (Ponte and Batista, 2019). The Americans dedicate nearly 8 hours a day to internet usage, with more than half of them using the computer daily, to the detriment of other activities (Roberts, 2000). On average, they devote three daily hours to surfing the web, being that $57 \%$ of this time is spent on email, instant messages and chats. Adults use the e-mail more often than teenagers, who use instant messages and chats more frequently (Nie et al., 2004).

Given the values that guide the individual and family life, the theoretical possibility of this study is that the Catholic religion is a relevant factor when choosing the place where internet access is available, and the time devoted to it.

\section{LARGE CATHOLIC FAMILIES}

A family is a polysemic subjective concept, which definition depends on the social, political and demographic context. It involves many religious, moral, legal, cultural and social conceptions that provide family typologies according to nature and size (Osswald, 2015, Saraceno and Naldini, 2003, Segrin and Flora, 2011, Simionato and Oliveira, 2003).

At the beginning of the 20th century, a family was seen as the relationship between a man (father), a woman (wife) and their child, in which the man assumed the main role (Durkheim, 1975, Parsons, 1971). As the years went by, the ideology of family, marriage and conjugality acquired a new paradigm, where Portugal is included (Aboim, 2005a, Aboim, 2005b, Amaro, 2014, Dias, 2011, Wall, 2005, Wall and Guerreiro, 2005).

Regarding the size of the family, despite the lack of documentation (Hutchins, 2013), it is said that a family with three or more children is considered a large family (Drysdale et al., 1984, Fahey et al., 2012, Knowlton, 1832, Rogers and Nikkel, 1979). According to the European Large Families Confederation (ELFAC) and the Portuguese Association for Large Families (APFN), a family with 3 or more children is considered large.

Even though it's open to change, Catholic Church defines the family as built by the father, mother and children, in several biblical texts. The ideology of family is defined on the basis of the "emotional ties and mutual consent"(Goody et al., 1995). In this conception, the children are seen as "God's blessings" or as gifts given by God to the couple. Therefore, it is not uncommon to find Catholic families in which the children assume the central role which is "intrinsic to the religious ideology" (Goody et al., 1995). In this paper, a large Catholic family is one with three or more children, where the commandments of the Catholic Doctrine are prophesied. 


\section{METHODOLOGY}

Mixed methods research was the strategy adopted, since quantitative and qualitative methods were used to gather data and evidence, which was later triangulated. This approach is frequently used in investigation on social sciences, namely in the studies about communication and the media.

Two samples were formed with two different purposes: a national sample of families $(\mathrm{N}=333)$, using simple random sampling, where questionnaires were applied; and a regional snowball sample $(\mathrm{N}=39)$ where families were interviewed and observed, with semi-structured interviews, field diaries and non-structured observation.

The accuracy of the sample along with its unanimity construction allowed the overcoming of the “answers' superficiality" (Quivy \& Campenhoudt, 2008, pp. 189-190). The semi-structured interview allowed the exploration of certain ideas, testing of answers, investigation of motives and feelings, things a questionnaire would never do (Bell, 1997). The field diaries allowed a thorough comprehension of the role of a computer connected to the internet in the family environment. The observation consisted of the spontaneous collection of data, capture of authentic moments and learning of behaviors and events in the specific moments these happened (Quivy and Campenhoudt, 2008). The interview data and field diaries were analyzed based on the "speech-cognition-society" (Van Dijk, 2000, Van Dijk, 2006), because of the wide understanding of "speech", in other words, as a "communicative event". This includes the face-to-face interaction, writing as well as body, facial language, text formatting, images and any other semiosis (Van Dijk et al., 2013).

\subsection{Samples}

The used qualification criterion was the same for both samples: large, Catholic, wealthy families. Altogether, both samples totalize 372 individuals, as depicted in Table 1.

Table 1. Depiction of national and regional samples

\begin{tabular}{llll}
\hline Participants & National & Regional & Total \\
\hline Parents & 128 & 14 & 142 \\
Children & 205 & 25 & 230 \\
Total & $\mathbf{3 3 3}$ & 39 & 372 \\
\hline
\end{tabular}

Most of the parents are aged of 42-47, with higher education degrees (79\%) and work as specialists in intellectual and scientific activities (52\%). The children are aged between of 12-13 and the majority of them $(97 \%)$ attends school. $26 \%$ of these are currently on the 9th grade, followed by 6 th graders $(25 \%)$ and fourth graders $(24 \%)$.

All respondents, parents and children, follow the foundations of the Catholic Church. However, the majority of parents (68\%) and children (62\%) don't attend any specific religious community. Around $30 \%$ of parents and $27 \%$ of children are integrated in some kind of religious community. Amongst the communities that have a higher number of followers are the Teams of Our Lady (28\%), Schoenstatt Apostolic Movement $(16 \%)$ and the Neocatechumenal Way (14\%). With the same percentage of answers (9\%) are the Emmanuel Community, Opus Dei and the Communion and Liberation. Regarding the children, the Neocatechumenal Way $(21 \%)$ and the Teams of Our Lady $(20 \%)$ are the most common.

\section{RESULTS}

In this section we present results concerning the number of computers connected to the internet, the location of those devices inside the families' houses and the time of exposure to the internet. 


\subsection{Number of Computers Connected to the Internet}

The national surveys - see Table 2 - show that $55 \%$ of the Portuguese Catholic families have a computer with internet connection at home, for $\mathrm{N}=333$. While the interviews and the field diaries show that there are 17 computers connected to the internet for $\mathrm{N}=39$.

Table 2. Number and location of the computer connected to the internet

\begin{tabular}{lcrcr}
\hline Type of device & \multicolumn{2}{c}{ National } & Regional/Local \\
\hline & $\begin{array}{l}\% \text { of families } \\
\text { computer connected to the } \\
\text { internet }\end{array}$ & $\begin{array}{l}\text { Location in the house } \\
\text { where the computers } \\
\text { connected to the internet } \\
\text { are } \\
\text { Shared }\end{array}$ & $\begin{array}{l}\text { Data from the interviews } \\
\text { and field diaries in absolute } \\
\text { value }\end{array}$ & \\
$\begin{array}{l}\text { Computer connected to the } \\
\text { internet }\end{array}$ & $54.8 \%$ & $86.2 \%$ & $13.8 \%$ & 17 \\
\hline
\end{tabular}

Even though the surveyed families belong to an educated, upper social class with no financial difficulties, the number of computers connected to the internet is low in the family environment. Therefore, it is clear that our data doesn't match the studies that mention Portugal as a country that is at the forefront regarding the number of personal computers (Livingstone et al., 2011, Ponte, 2011a, Ponte et al., 2012), nor there is a direct relation between family income and available amount of devices. The low number of digital devices is due to the fact that parents value sharing. This orients not only the amount, but also the location and time dedicated to the media/IT, as we will verify later. Since sharing is something that's encouraged since childhood, there was no competition nor family conflicts for the use of the media/ICTs. This goes against Mesch's perspective (2006), which states that the bigger the family, the higher the levels of conflict for the use of the media. He adds that teenagers may see shared access to the media platforms as a restriction of autonomy (Mesch, 2006). Therefore, it is common to listen to parents and children saying that the fact that there's only one computer is positive, since it allows sharing. This confirms that large families are formed by people who share feelings and values molding ties of interest, solidarity and reciprocity (Simionato and Oliveira, 2003).

\subsection{Location of Computers Connected to the Internet}

In terms of location, the computers connected to the internet are usually placed in shared spaces that can be accessed easily and quickly, instead of private spaces (Livingstone, 2002, Hall, 1990). There's no intention of moving them to private rooms (mother C), since they promote, for example, "isolation" or "sharing" (mother G). Parents want a family environment that allows for intrapersonal communication and avoids isolation. These results don't support the idea that Portugal is a country where media platforms are located in private rooms, like the bedroom (Livingstone et al., 2011, Ponte, 2011a, Ponte, 2011b, Ponte et al., 2012). They also don't support the privatization, individualization and consumerism perspective, nor the easiness of mobility and privacy on the internet that the abundance of portable computers and networks allowed. The promotion of the value of sharing allows the practice of other values, like "solidarity" (mother G), "participation" (father A) or "common good" (mother G; father A).

Regarding the amount, location and time of use, the father figure may be more important than the mother one. This exposes not only the gender inequality, noticeable in the Portuguese family environment (Wall, 2005), but also the idea passed on by the Catholic Church that "the lack of a father-figure in many families causes major imbalances in households and uncertainty in gender identification in children" (Synod of Bishops, 2014, p.27) Excerpts of the interviews reveal just that: "My father is usually the one who decides [on the purchase] For example, the computer So, we choose, then my father sees if (laughs) the price is fit or not" (daughter F3); "My father is the one who decides that it should be this way [amount, type and location] and that's it!" (daughter A3). 


\subsection{Time of Exposure the Internet}

Relating to the time spent on the internet, questionnaires show that, on a national level, $11 \%$ of parents and $6 \%$ of children don't use it. $34 \%$ of parents surf the web up until thirty minutes, $28 \%$ of children surf the web for between thirty minutes and one hour, $5 \%$ of parents and $10 \%$ of children surf the web three or more daily hours, as depicted in Table 3. The interviews and the field diaries confirm that people don't spend a lot of time on the internet. The majority dedicates the internet around two daily hours, this mainly during the week. When compared to the majority of Portuguese people, that surf the web for more than two daily hours, sometimes getting to five daily hours, these results are rather low.

Table 3. Daily time spent on the internet (regional/local) $\mathrm{N}=39$

\begin{tabular}{lcccccc}
\hline & 0 hours & Up to 30 min & 30 min-1 hour & 1 hour-2 hours & 2 hours-3 hours & 3 hours or more \\
\hline Children & 10 & 2 & 6 & 5 & 0 & 2 \\
Parents & 3 & 7 & 1 & 2 & 1 & 0 \\
\hline
\end{tabular}

For these families, time is a "value", it's a "gift of God" and it should be dedicated to the family or educational activities like reading, scouting, or catechesis, instead of using the internet, namely social networks like Facebook, Twitter or Instagram. The concept of time in the families of this research reflects the principles of the Catholic Church, as shown in statements of the participants:

- "it is a Christian standard, so we, as Christians, can't waste time... It is a gift of God" (father D);

." Time is a great value... it's a little related to faith..." (mother D);

-" We don't waste a lot of time, that's it! ...we have to use it to talk about our lives, problems, to pray" (father F);

-" Thinking if there's a lot of time for praying and I pray, here at home, instead of being on the internet. Hum, I also spend more time with my family than being on the internet..." (daughter F6).

Mostly, a time of use is not established, since the children agree not to spend a lot of it on the internet, spending their time on other activities. It is common that each one has a limited period of time for the use of the internet, as shown in this excerpt of the interview: "It's usually about an hour, an hour and a half for each, and no time in the morning. That's when we help out, read, play and that's it!" (Son C5); "When I'm on vacation, my mom gives me a little more time for the computer. She usually does (son B4)". The qualitative analysis also reveals that the time of exposure to the internet should be controlled. This perspective is found in the statements of both parents and children, as well as the idea that it's up to the parents to ensure that the family uses the internet in a "cautious" and "moderate" way. As the main guardians for education, it is the parent's duty to control their children. In fact, for these families, this role itself is a value (Dias, 2011).

\section{CONCLUSION}

We attempted to understand the time and location of the use of the internet in large Portuguese Catholic families, mentioning the role of religion.

In conclusion, the number of computers connected to the internet is low and they are found mainly in shared rooms, not private ones. This makes sharing easier and prevents isolation. The time of exposure is also short: parents spend a daily amount of 30 minutes maximum on the internet, while children dedicate between thirty minutes and one hour to it. Time should be dedicated to doing things that please the Lord because time is sacred. This restrains the use of the internet, which doesn't have an active role in these families.

This work is not without limitations, as we believe that bigger samples would increase its robustness and the level of trust in the obtained results.

Despite this limitation, we consider that this study introduced new family environments in which the time and location of the use of the internet do not obey the (apparent) generalized trend of the omnipresence of internet and technology amongst the families.

For future work, we set the studies of mobile devices as well as studies with bigger samples and ones that have different particularities. This will allow the identification of other uses of the internet that don't fit the (apparent) generalized trend in the majority of families. 


\section{REFERENCES}

Aboim, S. 2005a. As orientações normativas da conjugalidade. Famílias em Portugal-Percursos, Interacções, Redes Sociais, 169-230.

Aboim, S. 2005b. Dinâmicas de interacção e tipos de conjugalidade. Famílias em Portugal. Percursos, Interacções, Relações Sociais, Lisboa, Imprensa de Ciências Sociais, 231-302.

Amaro, F. 2014. Sociologia da família, Lisboa, Pactor.

Bell, J. 1997. Como realizar um projecto de investigação. Gradiva.

Dias, M. O. 2011. Um olhar sobre a família na perspetiva sistémica no processo de comunicação no sistema familiar. Gestão e desenvolvimento, 19, 139-156.

Drysdale, C. V., Ellis, H., Robinson, W. J. \& Grotjahn, A. 1984. Small or large families: Birth control from the moral, racial and eugenic standpoint.

Durkheim, E. 1975. Textes, fonctions sociales et institutions, Paris, Minuit.

Fahey, T., Keilthy, P. \& Polek, E. 2012. Family relationships and family well-being: A study of the families of nine year-olds in Ireland. Dublin: University College Dublin and the Family Support Agency, 1-108.

Goody, J., Barradas, A. \& Mariz, J. 1995. Família e casamento na Europa.

Hall, E. T. 1990. The hidden dimension, United States of America, Anchor.

Hutchins, H. R. 2013. Cheaper by the dozen: communication in large families.

INE. 2017. Portal do Instituto Nacional de Estatística [Online]. Available: www.ine.pt [Accessed 10 fevereiro 2018].

INE. 2018. Portal do Instituto Nacional de Estatística [Online]. Lisboa Instituto Nacional de Estatística. Available: www.ine.pt [Accessed 12 dezembro 2018].

Knowlton, C. 1832. Fruits of philosophy. San Francisco: The Reader's Library.

Lee, S. J. 2009. Online communication and adolescent social ties: Who benefits more from Internet use? Journal of Computer-Mediated Communication, 14, 509-531.

Lenhart, A., Rainie, L. \& Lewis, O. 2001. Teenage life online: The rise of the instant-message generation and the Internet's impact on friendships and family relationships. 1-46.

Livingstone, S. 2002. Young people and new media: Childhood and the changing media environment, Sage.

Livingstone, S., Haddon, L., Görzig, A. \& Ólafsson, K. 2011. EU kids online II: final report 2011.

Mesch, G. S. 2006. Family relations and the Internet: Exploring a family boundaries approach. The Journal of Family Communication, 6, 119-138.

Monteiro, T. L. \& Policarpo, V. 2011. Media e entretenimento. In: MATTOSO, J. (ed.) História da vida privada em Portugal. Maia: . Maia: Temas e debates

Morgan, D. 1996. Family connections: An introduction to family studies, Polity Press Cambridge.

Nie, N. H., Simpser, A., Stepanikova, I. \& Zheng, L. 2004. The ten years after the birth of the Internet, how do Americans use the Internet in their daily lives?, Stanford Center for the Quantitative Study of Society, 2-20.

Osswald, H. 2015. Em Torno da história da família. In: FERNANDES, O. M. \& MAIA, C. (eds.) A família portuguesa no século XXI. Lisboa: Parsifal.

Parsons 1971. A estrutura social da família. In: ASHEN, R. (ed.) A família: Sua função e destino Lisboa: Edições Meridiano.

Ponte, C. 2011a. Acessos e literacias digitais: resultados portugueses do inquérito europeu EU Kids Online. Literacia, Media e Cidadania, 23-38.

Ponte, C. 2011b. Uma geração digital? A influência familiar na experiência mediática de adolescentes. Sociologia, problemas e práticas, 31-50.

Ponte, C. \& Batista, S. 2019. EU Kids Online Portugal. Usos, competências, riscos e mediações da internet reportados por crianças e jovens. EU Kids

Ponte, C., Jorge, A., Simões, J. A. \& Cardoso, D. 2012. Crianças e internet em Portugal, Coimbra, Minerva.

Quivy, R. \& Campenhoudt, L. 2008. Manual de investigação em ciências sociais. , Lisboa, Gradiva.

Roberts, D. F. 2000. Media and youth: Access, exposure, and privatization. Journal of adolescent health, 27, 8-14.

Roe, K. 2000. Adolescents' media use: a European view. Journal of adolescent health, 27, 15-21.

Rogers, E. C. \& Nikkel, S. R. 1979. The housing satisfaction of large urban families. Housing and Society, 6, 73-87.

Saraceno, C. \& Naldini, M. 2003. Sociologia Da Família, Lisboa, Estampa.

Segrin, C. \& Flora, J. 2011. Family communication, Routledge.

Simionato, M. A. W. \& Oliveira, R. G. 2003. Funções e transformações da família ao longo da história. Anais do I Encontro Paranaense de Psicopedagogia, 57. 
Toffler, A. 1984 A terceira vaga, Lisboa, Livros do Brasil.

Van Dijk, T. A. 2000. Cognitive discourse analysis: an introduction. University of Amsterdam. Disponível em: www. discourses. org/MainPage2. html. Acesso em, 20, 2004.

Van Dijk, T. A. 2006. Discourse, context and cognition. Discourse studies, 8, 159-177.

Van Dijk, T. A., Medeiros, B. W. L. \& ANDRADE, M. L. C. 2013. Análise crítica do discurso multidisciplinar: um apelo em favor da diversidade. Linha D'Água, 26, 351-381.

Wall, K. 2005. Famílias em Portugal, Lisboa, Imprensa de Ciências Sociais.

Wall, K. \& Guerreiro, M. D. 2005. A divisão familiar do trabalho. In: WALL, K. (ed.) Famílias em Portugal Lisboa: Imprensa das Ciências Sociais. 